\title{
Effect of Burkholderia contaminans on Postharvest Diseases and Induced Resistance of Strawberry Fruits
}

\author{
Xiaoran Wang ${ }^{\dagger}$, Junfeng Shi ${ }^{\dagger}$, and Rufu Wang* \\ College of Horticulture, Shanxi Agricultural University, Taigu, Shanxi P.R., 030801, China \\ (Received on February 1, 2018; Revised on May 5, 2018; Accepted on May 25, 2018)
}

This study takes strawberry-fruits as the test material and discusses the effect of Burkholderia contaminans B-1 on preventing postharvest diseases and inducing resistance-related substances in strawberry-fruits. Soaking and wound inoculating is performed to analyze the inhibitory effects of different treatment solutions on the gray mold of postharvest strawberry-fruits. The count of antagonistic bacteria colonies in the wound is found, and the dynamic growth of antagonistic bacteria and the pathogenic fungus is observed by electron microscopy. The results indicated that, either by soaking/ wound-inoculating, the fermentation and suspension of antagonistic bacteria significantly reduced the incidence of postharvest diseases of strawberry-fruits. With wound inoculation, the inhibition rate of antagonist fermentation and suspension $\left(1 \times 10^{10} \mathrm{cfu} / \mathrm{ml}\right)$ respectively reached $77.4 \%$ and $66.7 \%$. It also led to a significant increase in the activity of resistance-related enzymes, i.e., phenylalanine ammonia lyase (PAL), 4-coumarate coenzyme A ligase (4CL), cinnamate-4-hydroxylase (C4H) and chalcone isomerase (CHI). On $1 \mathrm{~d}$ and $2 \mathrm{~d}$ post-treatment, the activity of $4 \mathrm{CL}$ was respectively 3.78 and 6.1 times of the control, and on $5 \mathrm{~d}$, the activity of PAL was increased by 4.47 times the control. The treatment of antagonistic bacteria delayed the peaking of cinnamyl-alcohol dehydrogenase (CAD) activity and promoted the accumulation of lignin and total phenols. The antagonistic bacteria could be well colonized in the

\footnotetext{
${ }^{\dagger}$ These authors contributed equally to this study

*Corresponding author.

Phone) +86 13603546976, FAX) +86 2164085875

E-mail)wxrwrf@126.com

(c) This is an Open Access article distributed under the terms of the Creative Commons Attribution Non-Commercial License (http:// creativecommons.org/licenses/by-nc/4.0) which permits unrestricted noncommercial use, distribution, and reproduction in any medium, provided the original work is properly cited.
}

Articles can be freely viewed online at www.ppjonline.org. wounds. On 4-5 d post-inoculation, the count of colonies was $10^{8}$ times of that upon inoculation. Electronmicroscopy indicated that the antagonistic bacteria delayed the germination of pathogenic spores in the wounds, and inhibited further elongations of the mycelia.

Keywords : Burkholderia contaminans B-1, induced resistance, postharvest diseases, strawberry

Handling Associate Editor: Oh, Chang-Sik

Strawberry (Fragaria ananassa Duch.) belongs to the Rosaceae family, and its fruit is of bright color, sweet and sour in taste, and highly nutritious. This makes the strawberry fruit of high nutrition as well as economic value, but since the fruit tissue is soft and delicate, it is prone to mechanical injuries and pathogen infections, and these may result in significant economic loss (García et al., 1998). Contemporarily, chemical fungicides have been the primary control measures to prevent postharvest diseases of strawberry fruits, but the adverse effects of fungicides on the environment and human health, and the resistance of pathogenic microorganisms have increasingly limited the use of fungicides (Ghaouth et al., 2004; Wei et al., 2014). Therefore, it is imperative to find other methods to prevent and control postharvest diseases (Kim et al., 2015).

With the identification of plant immunity and its application in field control of crop diseases, it was gradually discovered that for vegetables and fruits, resistance to diseases could be induced either by physical, chemical or biological methods, and this process was accordingly named postharvest induced resistance (Bi et al., 2007; Terry and Joyce, 2004). Multiple factors, including physical, chemical and biological factors, could induce plant resistance. Among all previously reported inductive factors, antagonistic microorganisms have attracted considerable attention among 
researchers, because they cause no pollution, no drug resistance, and no harm to human body (Sharma et al., 2009; Wisniewski and Wilson, 1992). Many studies have concluded that, antagonistic microorganisms can not only prevent postharvest diseases of vegetables or fruits (Hofstein and Fridlender, 1994; Wilson and Wisniewski, 1994) but also act as elicitors to induce resistance of fruits (Adikaram et al., 2002; Droby et al., 2002), therefore biologic antagonists could be used as an effective and feasible method to induce resistance of plants and prevent postharvest diseases (Droby et al., 2009).

Many studies reported the biological factor-induced resistance of fruits and vegetables. For example, Zhao et al. (2008) treated cherry tomato with Pichia guilliermon$d i i$, and found the treatment to have significantly reduced postharvest Rhizopus rot, and changed the activity of POD (peroxidase), PPO (polyphenol oxidase), SOD (superoxide), and CAT (catalase) in the fruits. Wisniewski and Wilson (1992) reported that treating apple, peach, and orange with antagonistic yeast $P$. guilliermondii significantly induced the activity of PAL (phenylalanine ammonialyase). Ippolito et al. (2000) inoculated apple with Aureobasidium pullulans during the storage period and found the treatment significantly improved the activity of POD, CHI (chalcone isomerase) and $\beta$-1,3-glucanase. Until now, no study has reported the effect of Burkholderia contaminans (B. contaminans) on postharvest disease, so in this study, strawberry fruits were taken as the test material to evaluate whether $B$. contaminansis able to inhibit postharvest gray mold and induce resistance in strawberry, and thus to provide a theoretical basis for the application of biological antagonists in postharvest disease control of strawberry fruits.

\section{Materials and Methods}

Antagonistic bacteria. B. contaminans B-1 was isolated by our laboratory from the surface of apricot, and identified according to its $16 \mathrm{~S}$ rDNA sequence in combination with its physiological and biochemical characteristics. The rat acute toxicity test, rabbit skin and eye sensitization test and guinea pig skin sensitization test confirmed that the strain was non-toxic and allergenic (tested by the Department of Hygiene Toxicology, School of Public Health, Shanxi Medical University). The strain was preserved at $-80^{\circ} \mathrm{C}$. For usage, it was first activated by culturing on a LB plate (peptone $10 \mathrm{~g}$, sodium chloride $5 \mathrm{~g}$, yeast extract $10 \mathrm{~g}$ and distilled water $1000 \mathrm{ml}, \mathrm{pH}$ 7.2), and then single colonies were inoculated into liquid LB medium $(50 / 250 \mathrm{ml})$ and shaken at $28^{\circ} \mathrm{C}$ and $200 \mathrm{r} / \mathrm{min}$ for $24 \mathrm{~h}$.
Pathogen. Botrytis cinerea (B. cinerea) was isolated from strawberry fruits with natural decay, and identified according to the morphological characteristics. The strain was preserved at $-4^{\circ} \mathrm{C}$, and for usage, it was inoculated onto a PDA plate (potato $200 \mathrm{~g}$, glucose $20 \mathrm{~g}$, agar $15 \mathrm{~g}$ and distilled water $1000 \mathrm{ml}, \mathrm{pH} 6.8$ ) and cultured at $26^{\circ} \mathrm{C}$ for $5-7$ $\mathrm{d}$. Then, conidiophores were obtained, counted, and made into suspension with a concentration of $1.0 \times 10^{5}$ spores $/ \mathrm{ml}$.

Fruits. The "Hongyan" strawberry fruits were picked from greenhouses in Dongyang Town, Jinzhong, Shanxi. All fruits were obtained from the same greenhouse. Matured fruits with uniform sizes and no mechanical injuries or diseases were collected in the morning and immediately transported back to the laboratory and stored at $0^{\circ} \mathrm{C}$.

The inhibition of fruit decay by the antagonistic bacteria. The effect of different B-1 solutions on strawberry fruits inoculated with $B$. cinerea: Healthy strawberries were selected and a wound with $4 \mathrm{~mm} \times 4 \mathrm{~mm}$ in size was made on the surface by using a sterilized needle. Then, the following solutions $(40 \mu \mathrm{l})$ were applied to the wound of strawberries: A) B-1 fermentation with a concentration of $1 \times 10^{10} \mathrm{cfu} / \mathrm{ml}$; B) $1 \times 10^{9} \mathrm{cfu} / \mathrm{ml} \mathrm{B}-1$ fermentation; C) $1 \times 10^{8} \mathrm{cfu} / \mathrm{ml} \mathrm{B-1}$ fermentation; D) $1 \times 10^{10} \mathrm{cfu} / \mathrm{ml} \mathrm{B-} 1$ suspension: After centrifuging the B-1 fermentation (1 $\times 10^{8} \mathrm{cfu} / \mathrm{ml}$ ) at $10000 \mathrm{~g}$ for $10 \mathrm{~min}$, the supernatant was discarded and the precipitant was re-suspended using an equivalent volume of sterile water; E) B-1 filtrate: The supernatant of filtered B-1 fermentation $\left(1 \times 10^{10} \mathrm{cfu} / \mathrm{ml}\right)$ through a $0.45-\mu \mathrm{m}$ membrane; F) Heat-killed B-1 solution: The B-1 fermentation was heated at $121^{\circ} \mathrm{C}$ for $20 \mathrm{~min}$; and CK: sterile water. After applying the solutions, fruits were blown by sterile wind for $2 \mathrm{~h}$ and added with the $B$. cinerea suspension $\left(1 \times 10^{5}\right.$ spores $\left./ \mathrm{ml}\right)$. In the subsequent step, it was cultured at $16^{\circ} \mathrm{C}$ for $8 \mathrm{~d}$, following which are the calculation of disease incidence and the measurement of mold diameter. Each repeat had 30 fruits, and each treatment had 3 repeats.

The effect of B-1 solutions with different concentrations on naturally decayed strawberry fruits: Healthy strawberry fruits were soaked relatively in the following solutions: A) B-1 fermented stock; B) B-1 fermentation broth (diluted 5 times); C) B-1 fermentation broth (diluted 10 times); D) B-1 bacterial suspension stock; E) B-1 bacterial suspension (diluted 5 times); 6) B-1 bacterial suspension (diluted 10 times); 7) CK1: sterile water; and 8) CK2: untreated. After being soaked in the above solutions for $2 \mathrm{~min}$, strawberry fruits were dried with sterile wind, packed in PE plastic 
bags and preserved respectively at $16^{\circ} \mathrm{C}$ for $15 \mathrm{~d}$. Afterwards, the condition of fruits stored at two temperatures was examined, and the incidence of gray mold, as well as the index of decay, was calculated. Each repeat had $1000 \mathrm{~g}$ of fruits, and each treatment had 3 repeats.

Fruit decay was classified into 5 degrees. Degree 0: Fruits are intact without any decay; Degree 1: Fruits show mild lesion on the surface, with an area of decay smaller than $1 / 3$ of the total fruit surface; Degree 2: Fruits show obvious decay, which covers an area of 1/3-1/2 of the fruit surface; Degree 3: Over 1/2 of the fruit surface is decayed, but the fruit still bears certain hardness; Degree 4: The fruit is decayed completely. The index of fruit decay is calculated by the following formula:

Index of fruit decay $\%=$ Sum (No. of decayed fruits at each degree $\times$ degree of decay) / (highest degree of decay $\times$ No. of total fruits) $\times 100$

The effect of antagonistic bacteria on resistance-related enzymes in strawberry fruits. Fruit treatment: According to the method proposed by Bi et al. (2005), strawberries with uniform sizes and maturities, and with no mechanical injuries were selected and randomly assigned to the control and treatment group. For both groups, fruits were soaked in $2 \%$ sodium hypochlorite, dried with sterile wind, and made with a wound of $4 \mathrm{~mm}$ diameter and $4 \mathrm{~mm}$ depth in the equatorial part by using a sterilized needle. Then, the treatment group was applied with $40 \mu \mathrm{l}$ of $B$. contaminans B-1 fermentation, whereas the control was applied with an equivalent amount of sterile water. After drying the fruits by sterile wind for $2 \mathrm{~h}, 15 \mu \mathrm{l}$ of $B$. cinerea spore suspension $\left(1 \times 10^{5}\right.$ spores $\left./ \mathrm{ml}\right)$ was inoculated onto the wounds and cultured at $16^{\circ} \mathrm{C}$ for $5 \mathrm{~d}$. Each day, the fruit tissue at $5 \mathrm{~mm}$ distal to the wound was sampled, wrapped in foil, frozen by liquid nitrogen, and preserved at $-80^{\circ} \mathrm{C}$ for future measurements. Each repeat had 30 fruits, and each treatment had 3 repeats.

The detection of phenylalnine ammonia lyase (PAL) activity was performed in referring to the method of Zhao et al. (2008), and 1 unit of enzyme activity (U) was defined as a change of 0.01 in light absorbance at $290 \mathrm{~nm}$ per hour; The measurement of 4-coumarate coenzyme A ligase (4CL) activity was performed with the modified method of Wang et al. (2014), with 1 unit of enzyme activity (U) defined as a change of 0.1 in the absorbance at $333 \mathrm{~nm}$ per minute; The measurement of cinnamate-4-hydroxylase $(\mathrm{C} 4 \mathrm{H})$ activity was performed using modified method of Fan et al. (2012), with 1 unit of enzyme activity (U) defined as a change of 0.01 in the absorbance at $340 \mathrm{~nm}$ per minute; The detec- tion of chalcone isomerase (CHI) activity was performed according to the modified method of Lister et al. (2015), with 1 unit of enzyme activity (U) defined as a change of 0.01 in the absorbance at $390 \mathrm{~nm}$ per minute; The activity of cinnamyl-alcohol dehydrogenase (CAD) was measured using the modified method of Goffner et al. (1992), with 1 unit of enzyme activity defined as a change of 0.1 in the absorbance at $340 \mathrm{~nm}$ per minute; The detection of polyphenloxidase (PPO) activity was performed using the pyrocatechol method (Tian et al., 2002), with 1 unit of enzyme activity defined as an increase of 0.1 in the absorbance at $398 \mathrm{~nm}$ per minute, and the activity of peroxidase (POD) was detected using the Guaiacol method (Liu et al., 2010), with 1 unit of enzyme activity defined as an increase of 0.01 in the absorbance at $460 \mathrm{~nm}$ per minute. The measurement of each sample was repeated 3 times.

Detection of resistance-related substances: The amount of total phenols and flavonoids was performed using the modified method of Pirie and Mullins (1976), and the content was respectively presented as OD280 $\mathrm{g}^{-1} \mathrm{FW}$ and OD325 $\mathrm{g}^{-1} \mathrm{FW}$; The amount of lignin was determined using the modified method of Chen et al. (2014) and was presented as OD280 $\mathrm{g}^{-1} \mathrm{FW}$. The measurement of each sample was repeated 3 times.

Dynamic growth of antagonistic bacteria and pathogenic fungus in the wound of fruit. After inoculation of $B$. cinerea at the center of the PDA plate, two antagonizing bacteria B-1 straight lines were drawn on the right and left sides of Botrytis cinerea. The straight lines were at about 3 $\mathrm{cm}$ from the inoculation point. After 3 days culture at $26^{\circ} \mathrm{C}$, the mycelium of $B$. cinerea that is far from the antagonistic bacteria was used as a control and near B-1 as treatment. The control and treated pathogen mycelium were picked up respectively, and the morphology of mycelium was observed under scanning electron microscope. The dynamic growth of colonies at the wound was also observed under an electron microscope at $12 \mathrm{~h}, 24 \mathrm{~h}$, and $48 \mathrm{~h}$ post inoculation.

Data analysis. Statistical analysis was performed using the SPSS 16.0 software. Significance was tested by the Duncan new multiple range test.

\section{Results}

The effect of antagonist bacteria on postharvest strawberry fruits inoculated with pathogens. Fig. 1 shows the degree of decay after strawberry fruits were treated with 


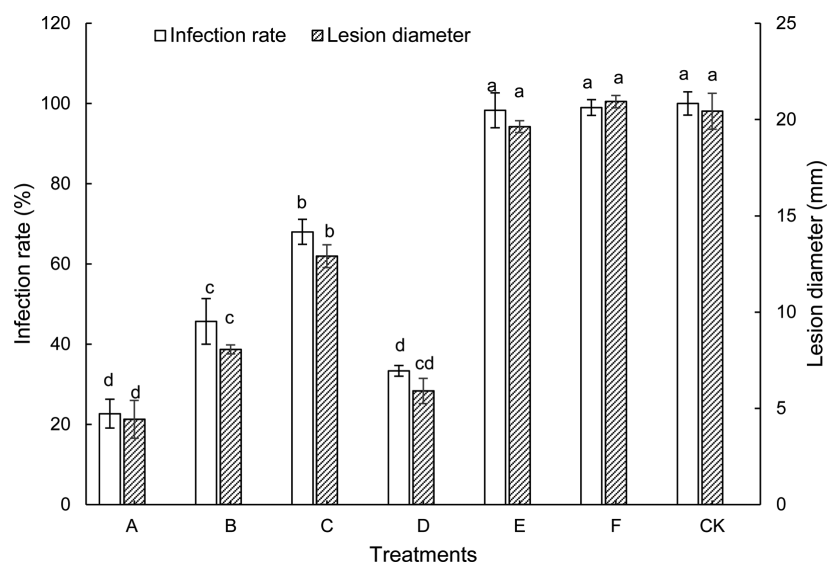

Fig. 1. The inhibitory effect of $B$. contaminans B-1 on postharvest strawberry fruits inoculated with pathogens. (A) $1 \times 10^{10} \mathrm{cfu} /$ $\mathrm{ml}$ fermentation; (B) $1 \times 10^{9} \mathrm{cfu} / \mathrm{ml}$ fermentation; (C) $1 \times 10^{8} \mathrm{cfu} /$ $\mathrm{ml}$ fermentation (D) $1 \times 10^{10} \mathrm{cfu} / \mathrm{ml}$ bacterial suspension (E) Filtrate; (F) Heat-killed fermentation; (CK) Sterile water.

different solutions and preserved at $16^{\circ} \mathrm{C}$ for $8 \mathrm{~d}$. Fruits in the control group were all diseased, with an infection rate

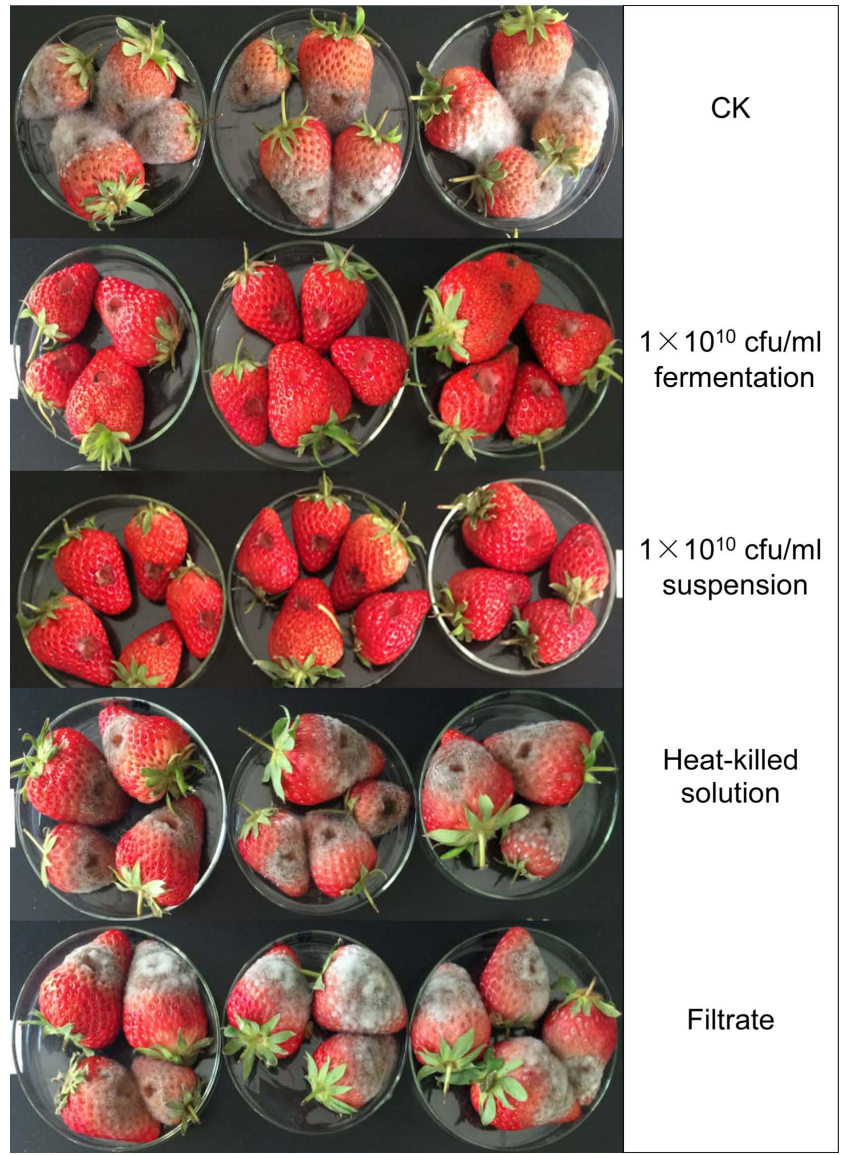

Fig. 2. Inhibitory effects of different B. contaminans B-1 treatments on postharvest gray mold of strawberry fruit. of $100 \%$ and a lesion diameter of $20.4 \mathrm{~mm}$. Strawberries treated with B-1 filtrate or heat-killed B-1 fermentation respectively had an infection rate of $99.1 \%$ and $100 \%$, bearing a lesion diameter of $20.9 \mathrm{~mm}$ and $19.6 \mathrm{~mm}$, which were insignificantly different from the control. However, with respect to those treated with B-1 fermentation and suspension, the rate of decay and the diameter of lesion were both significantly reduced; The B-1 fermentation treatment had an infection rate of $22.6 \%$ and a lesion diameter of $4.4 \mathrm{~mm}$, which respectively obtained an inhibition rate of $77.4 \%$ and $78.4 \%$ in comparison to the control; The B-1 suspension treatment had an infection rate of $33.3 \%$ and a lesion diameter of $5.9 \mathrm{~mm}$, and the inhibition rate was $66.7 \%$ and $71.1 \%$ respectively. And as the concentration of B-1 fermentation increases, the severity of the disease of the strawberry fruits also becomes lighter. The B-1 fermentation with $1 \times 10^{8} \mathrm{cfu} / \mathrm{ml}$ and $1 \times 10^{9} \mathrm{cfu} / \mathrm{ml}$ had an inhibition rate of $32.0 \%$ and $54.3 \%$ respectively in comparison to the control. The concentration of $1 \times 10^{10} \mathrm{cfu} / \mathrm{ml}$ fermentation broth is more effective than these two concentrations. Fig. 2 shows the inhibitory effect of partial treatment solution on postharvest gray mold of strawberry.

The effect of antagonistic bacteria on natural decay of strawberry fruits. Fig. 3 shows the decay index of strawberry fruits after they were treated differently and stored at $16^{\circ} \mathrm{C}$ for $15 \mathrm{~d}$. As indicated by the chart, both fermentation broth and bacterial suspension at different concentrations could inhibit postharvest decay of strawberry fruits. The decay index of CK1 (soaked in sterile water) and CK2

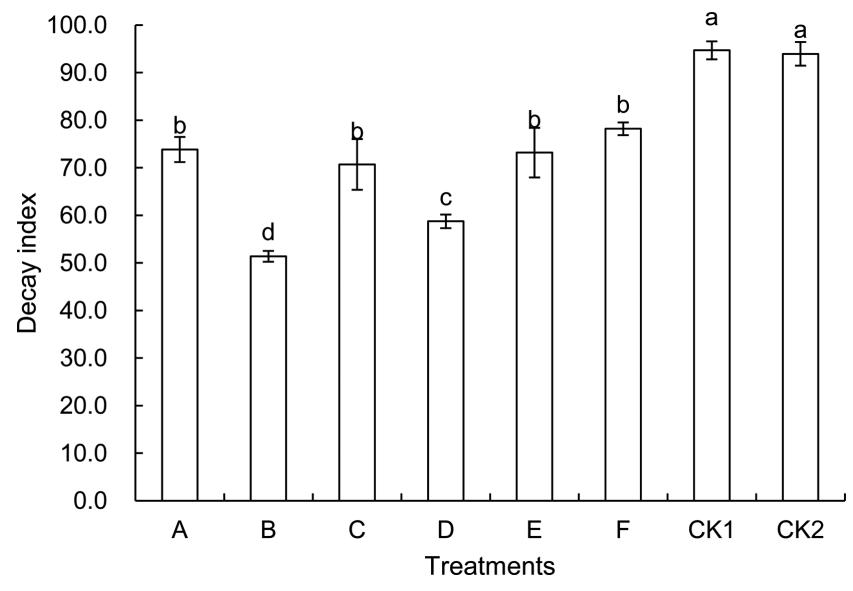

Fig. 3. The effect of $B$. contaminans B-1 on natural decay of strawberry fruits. (A) Fermented stock; (B) Fermentation broth (diluted 5 times); (C) Fermentation broth (diluted 10 times); (D) Bacterial suspension; (E) Bacterial suspension (diluted 5 times); (F) Bacterial suspension (diluted 10 times); (CK1) Sterile water; (CK2) Untreated. 
(untreated) fruits was 94.70 and 93.95 respectively, which were insignificantly different from each other. The fermentation stock in comparison with 10 times-diluted fermentation stock showed similar antiseptic effects, which had a

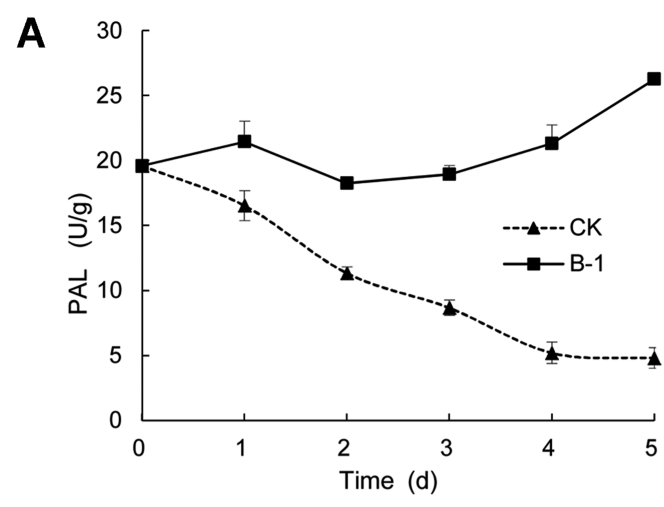

C

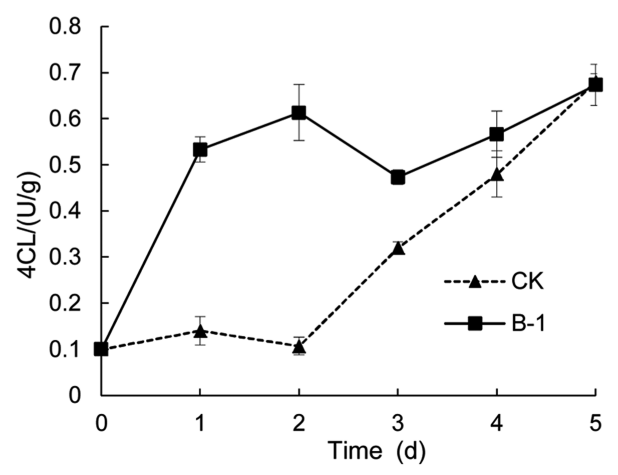

E
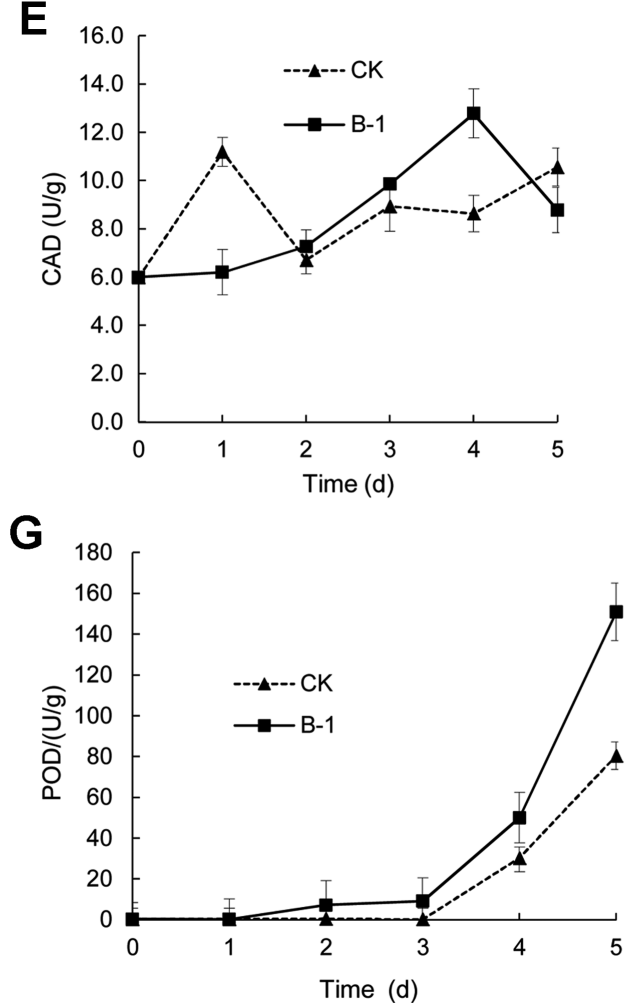

decay index of 73.83 and 70.70 respectively. On the other hand, the 5 times-diluted fermentation stock showed the most effective protection against fruit decay, with the decay index being 51.39 , and the inhibition rate being $45.3 \%$
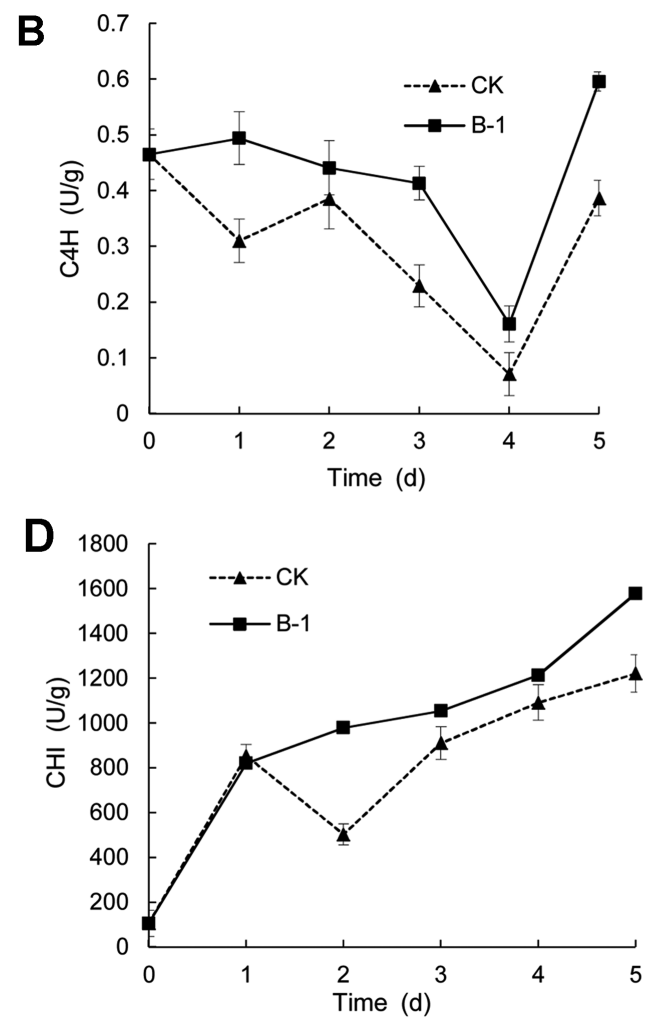

$\mathbf{F}$

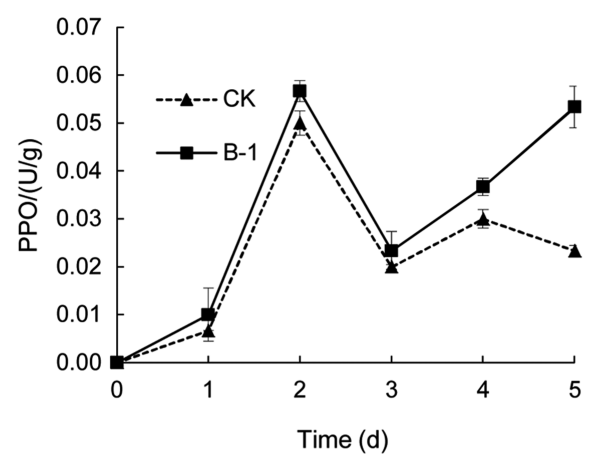

Fig. 4. The effect of $B$. contaminans B-1 on the activity of PAL (A); C4H (B); 4CL (C); CHI (D); CAD (E); PPO (F); POD (G) in postharvest strawberry fruits. 
in comparison to CK2. The bacterial suspension had the second highest efficacy in preventing fruit decay, and the inhibition rate was $37.47 \%$ when compared to the CK2.

The effect of antagonistic bacteria on the activity of enzymes involved in the phenylpropanoid pathway. As shown in Fig. 4A, the activity of PAL rose significantly with the increase of storage time in the B-1 treated group, with a small peak occurring on the second day. On the other hand, the control group showed an opposite trend, and by the 5th day, the PAL activity in antagonist-treated strawberries reached $26.27 \mathrm{U} / \mathrm{g}$, which was 4.47 times the control. During storage, the activity of $\mathrm{C} 4 \mathrm{H}$ varied in similar patterns between the treatment and control groups, which exhibited a declining trend in the first $4 \mathrm{~d}$ and a significant increase on the 5th day, but the activity of the treatment group was significantly higher than the control group (Fig. 4B). Fig. 4C demonstrates the change of 4CL activity in two groups, where the treatment group had a rising rate significantly higher than the control in the first 3 days, with significant difference identified on $1 \mathrm{~d}$ and $2 \mathrm{~d}$ (3.78 and 6.1 times higher than the control respectively), but then the increase was slowed down, and the enzyme activity on 5 $\mathrm{d}$ was insignificantly different between the two groups. In Fig. 4D, the activity of CHI showed an overall increasing trend during the storage period. The ascending rate of two groups was basically the same on $1 \mathrm{~d}$, but in the following days, the treatment group continued the growth whereas the control group showed an initial decrease and a subsequent

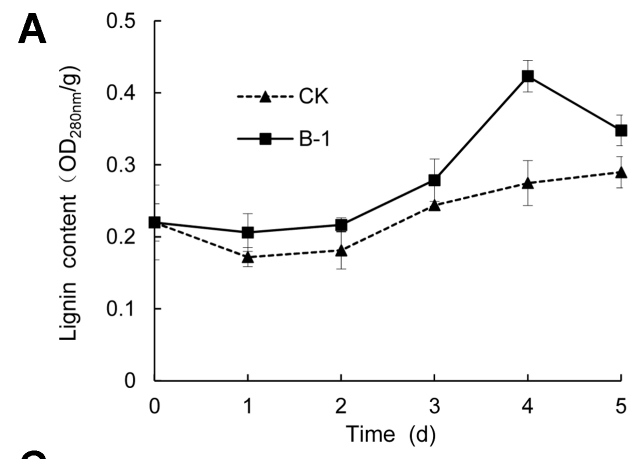

C

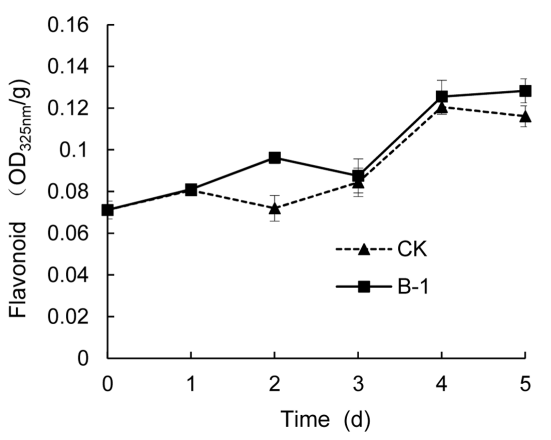

increase, and the level of enzyme activity of the treatment group was significantly higher than the control during these days. As shown in Fig. 4E, the activity of CAD reached the peak on $1 \mathrm{~d}$ in the control group, yet the peak of the treatment group occurred on $4 \mathrm{~d}$, which indicated that the antagonistic bacteria delayed the rising of enzyme activity, and induced its activation in the eventual phase of storage. What can be seen from Fig. $4 \mathrm{~F}$ is that the two groups had a similar variation of the PPO activity during the first $4 \mathrm{~d}$, where the level peaked at $2 \mathrm{~d}$ and decreased in the following days. In the first 3 days, the treatment group had an enzyme activity slightly higher than the control but the difference was not significant, and on $4 \mathrm{~d}$, the treatment group showed a marked increase, and on $5 \mathrm{~d}$, the treatment group continued to rise, whereas the control group experienced a decline, which resulted in a 2.5 -fold difference between the treatment group and the control group. Fig. 4G demonstrates that in the first $3 \mathrm{~d}$, the activity of POD in strawberry fruits stayed relatively low, but from $3 \mathrm{~d}$, enzyme activity started to increase in both groups, and the treatment group presented a rising rate significantly higher than the control.

The effect of antagonistic bacteria on resistance-related substances in strawberry fruits. It can be seen from Fig. $5 \mathrm{~A}$ that strawberries with antagonist treatment had a higher level of lignin. In the first 3 days, the treatment group was slightly different from the control group, but on $4 \mathrm{~d}$, the content of lignin increased dramatically and peaked at a level which was 1.5 times of the control. It can be seen

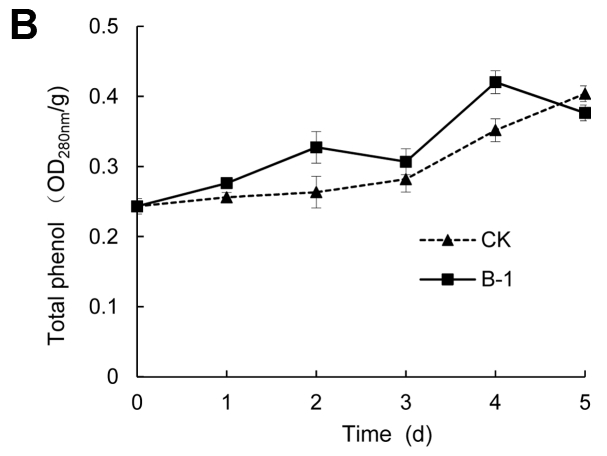

Fig. 5. The effect of $B$. contaminans B-1 on lignin (A) Total phenols (B) Flavonoids (C) In postharvest strawberry fruits. 


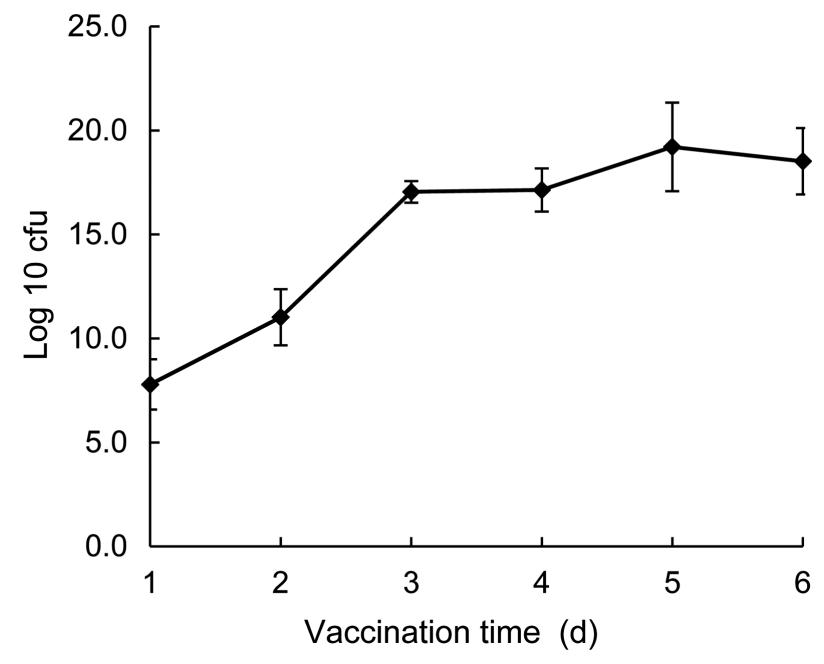

Fig. 6. The count of bacterial colonies of antagonistic bacteria in fruit wound.

from Fig. 5B that the total phenol content displayed an overall rising trend during the storage period, and the treatment group always had a level higher than the control, considering $5 \mathrm{~d}$ as an exception. While the control group increased steadily, the treatment group had two peaks on 2 $\mathrm{d}$ and $4 \mathrm{~d}$ respectively. Fig. $5 \mathrm{C}$ indicates that the treatment of antagonist bacteria did not significantly affect the level of flavonoid in strawberry fruits. The two groups showed little difference, only on $2 \mathrm{~d}$, the treatment group had a slightly higher level than the control.

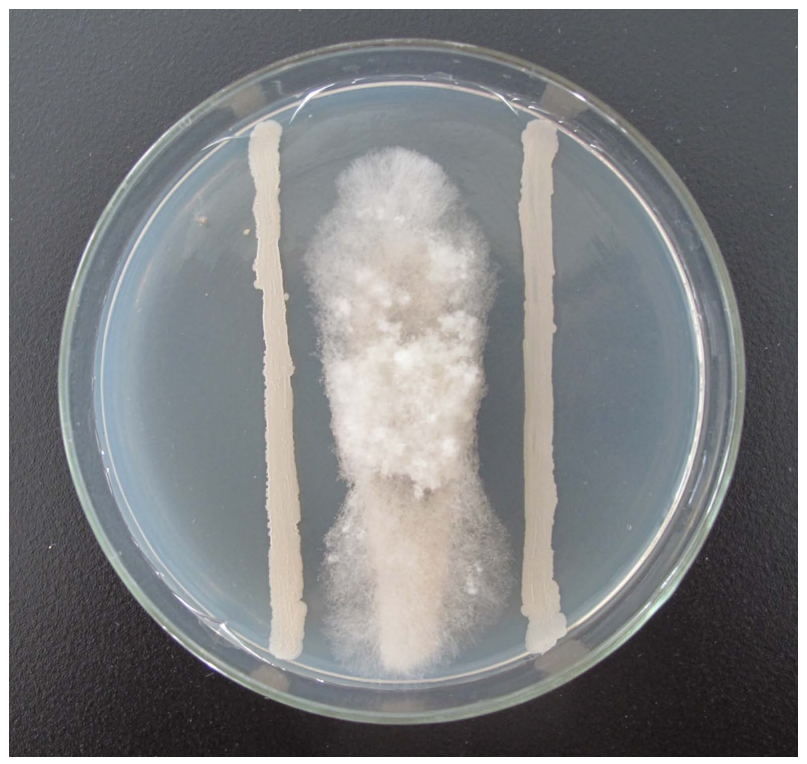

Fig. 7. Antagonistic Bacteria B-1 and Botrytis cinerea cultured in PDA medium.
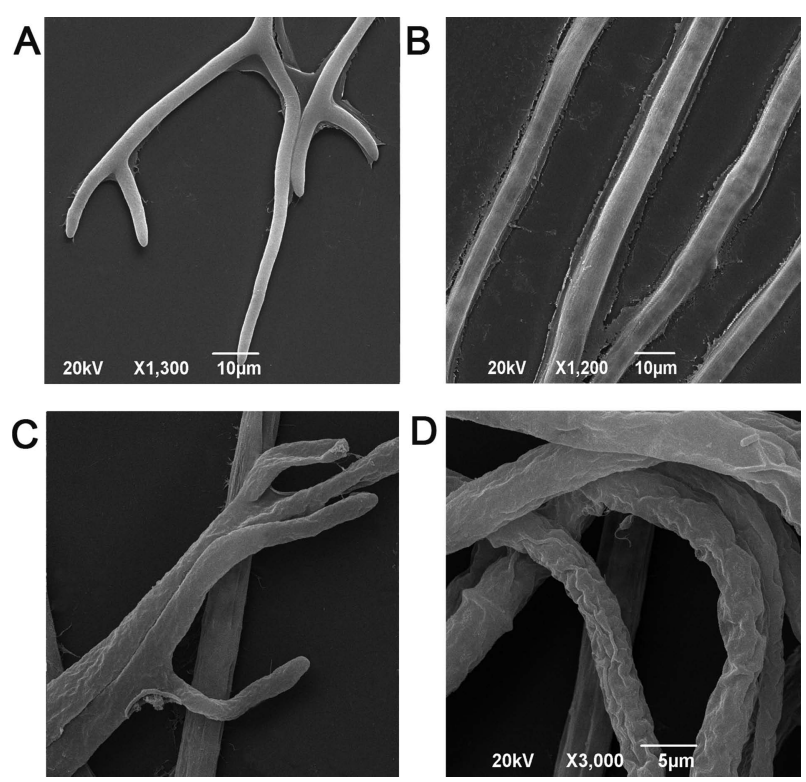

Fig. 8. Mycelial morphology of Botrytis cinerea growing normally (A, B) and affected by antagonistic bacteria $(C, D)$ under microscope.

Dynamic growth of antagonistic bacteria in fruit wounds. As shown in Fig. 6, the count of colonies increased steadily during the $5 \mathrm{~d}$ culturing under $25^{\circ} \mathrm{C}$. That is, the count of colonies started at $6.31 \times 10^{7} \mathrm{cfu} / \mathrm{ml}$ and increased rapidly to $1.91 \times 10^{11} \mathrm{cfu} / \mathrm{ml}$ at $1 \mathrm{~d}$ after inoculation. Following that, the number of colonies increased with time and plateaued at $1.2-3.2 \times 10^{19} \mathrm{cfu} / \mathrm{ml}$ on $4-5 \mathrm{~d}$, which was $10^{8}$ times of the level of $1 \mathrm{~d}$. This suggested that the antagonistic bacteria could be well colonized in the strawberry wound.

The growth of Botrytis cinerea on the PDA medium close to B-1 was inhibited, resulting in the formation of a significant zone of inhibition, while the other side of the mycelium was able to grow normally, so the shape of the colonies was banded (Fig. 7). The normally grown $B$. cinereamycelia is smooth in appearance, uniform in growth, and relatively strong (Fig. 8A, B); and the mycelia of B. cinerea close to the antagonistic bacteria is uneven in thickness, shrinkage, surface ulceration and containment spillover (Fig. 8C, D).

\section{Discussion}

The results of this study showed that the antagonistic bacteria B.contaminan B-1 effectively prevented postharvest decay of strawberry fruits during storage, and either by wound inoculation or natural decay, the antagonistic bacteria demonstrated good inhibitory effects against fruit 
decay. Our study also found that the B-1 fermentation and suspension had better effects than the filtrate or heat-killed solution, which can indicate that the antifungal substance is not secreted outside the cell, and it is not resistant to high temperature.

After inoculating the strawberry fruits with antagonist fermentation, the levels of resistance-related substances were markedly different from the control. The treatment of antagonistic bacteria significantly elevated the activity of PAL, which is the first key enzyme for phenylpropane metabolism (Mauch-Mani and Slusarenko, 1996), and this was consistent with the study of Jamet and Fritig (1986), which correspondingly reported that resistant varieties would show increased PAL activity post pathogen infection. 4CL and $\mathrm{C} 4 \mathrm{H}$ are the other two key enzymes following PAL. $\mathrm{C} 4 \mathrm{H}$ is associated with the synthesis of p-coumaric acid, which is the synthetic precursor of phenolic acids including coumaric acid, caffeic acid, and ferulic acid, all of which hold the ability to directly kill and inhibit the growth of pathogens in fruits. The enhanced $\mathrm{C} 4 \mathrm{H}$ activity would promote the biosynthesis of these phenolic acids (Dixon et al., 2010). 4CL controls a branched pathway of phenylpropane metabolism, and its metabolites including lignin, total phenols and flavonoids are important antifungal substances (Winkel-Shirley, 2001).

According to the results, the inoculation of antagonistic bacteria increased the activity of $\mathrm{C} 4 \mathrm{H}$ and $4 \mathrm{CL}$ during storage when compared with the control, and on $1 \mathrm{~d}$ and $2 \mathrm{~d}$, the $\mathrm{C} 4 \mathrm{H}$ activity of the treatment group was as high as 3.78 and 6.1 times of the control. Despite similar variations of the 4CL activity, the treatment group had a significantly higher level of enzyme activity, which was 1.5 times of the control. CHI is an important downstream enzyme of the phenylpropane pathway, and it functions to catalyze the synthesis of flavonoids and thereby enhancing the resistance of plants (Zheng et al., 2011). CAD is key to the synthesis of lignin (Luo et al., 2012). PPO and POD are terminal-related enzymes; The former holds the ability to oxidize phenolic substances and produce toxic quinones that can restrict and kill pathogenic microorganisms, and the latter is associated with the synthesis of lignin and phytoalexins (Dokoozlian et al., 1998). In this study, the antagonistic bacteria significantly elevated the activity of $\mathrm{CHI}$, PPO, and POD in the late period of storage, and delayed the occurring of $\mathrm{CAD}$ peak, which improved the resistance of postharvest strawberry fruits.

Lignin, total phenols, and flavonoids are metabolic end products of the phenylpropane pathway. As a major component of the cell wall, lignin functions to prevent the spreading of pathogenic microorganisms; Phenols are able to produce quinones that are highly toxic to pathogens; Flavonoids are important phytoalexins to prevent the germination of pathogenic spores as well as the elongation of germ tube, and to kill end cells of the mycelia (Ahuja et al., 2012). In this study, antagonistic bacteria increased the content of all three substances, and the lignin experienced the most significant elevation, which was $53 \%$ higher than the control on $4 \mathrm{~d}$. The total phenols were increased by $24 \%$ and $20 \%$ on $2 \mathrm{~d}$ and $4 \mathrm{~d}$ respectively, and the flavonoids indicated slight increase but the difference was not significant.

In conclusion, inoculation of antagonistic bacteria significantly resulted in the following:

1. Reduced the decay index of strawberry fruits during storage.

2. Increased the activity of enzymes related to the phenylpropane pathway.

3. Enhanced the accumulation of resistance-associated substances such as lignin and total phenols, and thereby significantly improved the postharvest resistance for strawberry fruits.

Therefore, inoculation of antagonistic bacteria could be used as a potential biological control against fruit decay during postharvest storage of strawberry fruits.

\section{Acknowledgment}

The authors are grateful to Shanxi Province Science and Technology Research Project (No. 201703D221010-1).

\section{References}

Adikaram, N. K. B., Joyce, D.C. and Terryc, L. A. 2002. Biocontrol activity and induced resistance as a possible mode of action for Aureobasidium pullulans against grey mould of strawberry fruit. Aust. Plant Pathol. 31:223-229.

Ahuja, I., Kissen, R. and Bones, A. M. 2012. Phytoalexins in defense against pathogens. Trends Plant Sci. 17:73-90.

Bi, Y., Tian, S. Zhao, J. and Ge, Y. 2005. Harpin induces local and systemic resistance against Trichothecium roseum in harvested hami melons. Postharvest Biol. Technol. 38:183-187.

Bi, Y., Li, Y. and Ge, Y. 2007. Induced resistance in postharvest fruits and vegetables by chemicals and its mechanism. Stewart Postharvest Rev. 3:1-7.

Chen, F. H., Zhang, M. Z. and Wu, G. B. 2014. Study of lignification's delaying and its relationship with energy metabolism in loquat fruits after nitric oxide fumigation. Sci. Agric. Sinica 47:2425-2434.

Dixon, R. A., Achnine, L., Kota, P., Liu, C. J., Reddy, M. S. S. and Wang, L. J. 2010. The phenylpropanoid pathway and plant defence-a genomics perspective. Mol. Plant Pathol. 3:371-390. 
Dokoozlian, N. K., Ebisuda, N. C. and Neja, R. A. 1998. Surfactants improve the response of grapevines to hydrogen cyanamide. HortScience 33:857-859.

Droby, S., Vinokur, V., Weiss, B., Cohen, L., Daus, A., Goldschmidt, E. E. and Porat, R. 2002. Induction of resistance to Penicillium digitatum in grapefruit by the yeast biocontrol agent Candida oleophila. Phytopathology 92:393-399.

Droby, S., Wisniewski, M., Macarisin, D. and Wilson, C. 2009. Twenty years of postharvest biocontrol research: Is it time for a new paradigm? Postharvest Biol. Technol. 52:137-145.

Fan, C. F., Bi, Y., Wang, Y. F., Ren, Y. L., Yang, Z. M. and Wang, Y. 2012. Effect of salicylic acid dipping on postharvest diseases and phenylpropanoid pathway in muskmelon fruits. Sci. Agric. Sinica 45:584-589 (in Chinese).

García, M. A., Martino, M. N. and Zaritzky, N. E. 1998. Plasticized starch-based coatings to improve strawberry (Fragaria $\times$ ananassa) quality and stability. J. Agric. Food Chem. 46:3758-3767.

Ghaouth, A. E., Wilson, C. and Wisniewski, M. 2004. Biologically-based alternatives to synthetic fungicides for the control of postharvest diseases of fruit and vegetables. In: Diseases of Fruits and Vegetables: Volume II, ed. by S. A. M. H. Naqvi, pp. 511-535. Springer, Dordrecht, Netherlands.

Goffner, D., Joffroy, I., Grima-Pettenati, J., Halpin, C., Knight, M. E., Schuch, W. and Boudet, A. M. 1992. Purification and characterization of isoforms of cinnamyl alcohol dehydrogenase from eucalyptus xylem. Planta 188:48-53.

Hofstein, R. and Fridlender, B. 1994. Development of production, formulation and delivery systems. In: Brighton Crop Protection Conference 1994: Vol.1: Pests and Diseases, pp. 12731280. British Crop Protection Council, Farnham, Surrey, UK.

Ippolito, A., Elghaouth, A., Wilson, C. L. and Wisniewski, M. 2000. Control of postharvest decay of apple fruit by Aureobasidium pullulans and induction of defense responses. Postharvest Biol. Technol. 19:265-272.

Jamet, E. and Fritig, B. 1986. Purification and characterization of 8 of the pathogenesis-related proteins in tobacco leaves reacting hypersensitively to tobacco mosaic virus. Plant Mol. Biol. 6:69-80.

Kim, H. M., Lee, K. J. and Chae, J. C. 2015. Postharvest biological control of Colletotrichum acutatum on apple by Bacillus subtilis hm1 and the structural identification of antagonists. $J$. Microbiol. Biotechnol. 25:1954-1959.

Lister, C. E., Lancaster, J. E. and Walker, J. R. L. 2015. Developmental changes in enzymes of flavonoid biosynthesis in the skins of red and green apple cultivars. J. Sci. Food Agric. 71:313-320.

Liu, F. J., Tu, K., Shao, X. F., Zhao, Y., Tu, S. C., Su, J., Hou, Y. P. and Zou, X. H. 2010. Effect of hot air treatment in combination with Pichia guilliermondii on postharvest anthracnose rot of loquat fruit. Postharvest Biol. Technol. 58:65-71.

Luo, Z., Feng, S., Pang, J., Mao, L., Shou, H. and Xie, J. 2012. Effect of heat treatment on lignification of postharvest bamboo shoots (Phyllostachys praecox f. prevernalis.). Food Chem. 135:2182-2187.

Mauch-Mani, B. and Slusarenko, A. J. 1996. Production of salicylic acid precursors is a major function of phenylalanine ammonia-lyase in the resistance of arabidopsis to Peronospora parasitica. Plant Cell 8:203-212.

Pirie, A. and Mullins, M. G. 1976. Changes in anthocyanin and phenolics content of grapevine leaf and fruit tissues treated with sucrose, nitrate, and abscisic acid. Plant Physiol. 58:468472.

Sharma, R. R., Singh, D. and Singh, R. 2009. Biological control of postharvest diseases of fruits and vegetables by microbial antagonists: A review. Biol. Control 50:205-221.

Terry, L. A. and Joyce, D. C. 2004. Elicitors of induced disease resistance in postharvest horticultural crops: A brief review. Postharvest Biol. Technol. 32:1-13.

Tian, S., Xu, Y., Jiang, A. and Gong, Q. 2002. Physiological and quality response of longan fruit to high $\mathrm{O}_{2}$ or $\mathrm{CO}_{2}$ atmospheres in storage. Postharvest Biol. Technol. 24:335-340.

Wang, J., Bi, Y., Wang, Y., Deng, J., Zhang, H. and Zhang, Z. 2014. Multiple preharvest treatments with harpin reduce postharvest disease and maintain quality in muskmelon fruit (cv. Huanghemi). Phytoparasitica 42:155-163.

Wei, Y., Mao, S. and Tu, K. 2014. Effect of preharvest spraying Cryptococcus laurentii on postharvest decay and quality of strawberry. Biol. Control 73:68-74.

Wilson, C. L. and Wisniewski, M. E. 1994. Biological control of postharvest diseases of fruits and vegetables-theory and practice. CRC Press, Boca Raton, FL, USA. 192 pp.

Winkel-Shirley, B. 2001. Flavonoid biosynthesis. A colorful model for genetics, biochemistry, cell biology, and biotechnology. Plant Physiol. 126:485-493.

Wisniewski, M. E. and Wilson, C. L. 1992. Biological control of postharvest diseases of fruits and vegetables: Recent advances. HortScience. 27:94-98.

Zhao, Y., Tu, K., Shao, X., Jing, W. and Su, Z. 2008. Effects of the yeast Pichia guilliermondii against Rhizopus nigricans on tomato fruit. Postharvest Biol. Technol. 49:113-120.

Zheng, Y., Sheng, J., Zhao, R., Zhang, J., Lv, S., Liu, L. and Shen, L. 2011. Preharvest L-arginine treatment induced postharvest disease resistance to Botrysis cinerea in tomato fruits. $J$. Agric. Food Chem. 59:6543-6549. 